\title{
鉄鋼のケイ光 $\mathbf{X}$ 線分析における誤差要因 $(\text { 第 } \mathbf{1} \text { 報) })^{*}$ 裝置に帰因する誤差一
}

\author{
杉 本 正 勝**
}

(昭和 38 年 8 月 26 日受理)

\author{
Part 1: Instrumental Error \\ Masakatsu SUGIMOTO \\ (Nippon Metal Industry Co., Ltd., Kawasaki Plant)
}

Causes of Error in Fluorescent X-ray Analysis of Stainless Steel

In the application of fluorescent X-ray analysis to routine analysis, it is of the utmost importance to determine the amount of error originating from the equipment, and also to minimize this error without any loss in working efficiency.

This report covers the results of an examination of the error originating from a standard type fluorescent X-ray spectrometer in analysis of stainless steels. It is shown that the daily repeated measurements of the main elements in stainless steels can be made with an accuracy of $0.3 \%$ in fluctuation.

\section{1. まえがき}

本誌に岡，根本，倉田らが鉄鋼の発光分光分 析に打ける誤差要因を発表して抢らるるが1), ケイ光X線分析法における誤差要因のまとまっ た報告は極めて少ない。

著者はケイ光X線分析法によって，ステンレ ス鋼の分析を行ない，乙の誤差要因とその対策 を検討し，本法学作業分析に用いるための一助 とした.

本分析に先達って予想される誤差要因は, Fig. 1 に示すようなものであった.

これら要因中一部は，すでに報告したが2 今回は分析条件決定のために検討した装置に帰 因する誤差の大きさとその対策につき報告す る.

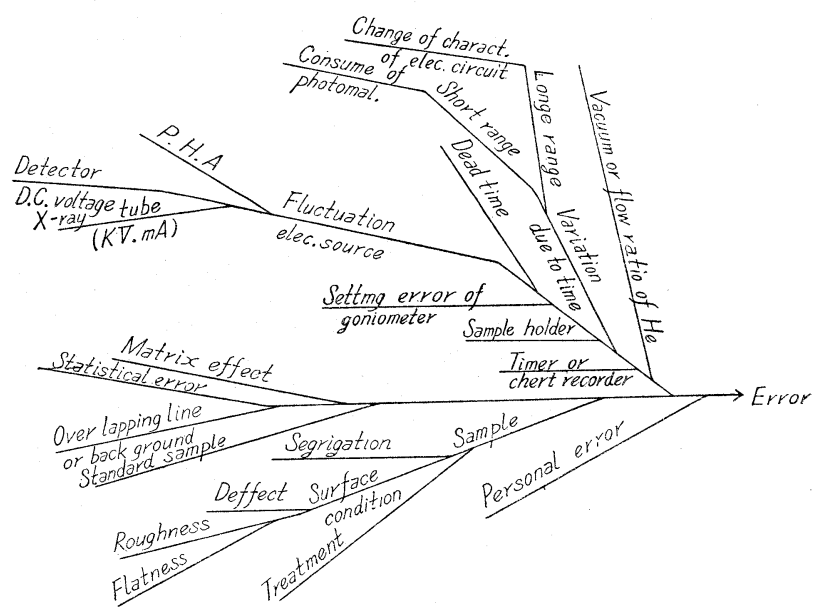

Fig. 1. Causes of error in the fluorescent X-ray analysis

*) 日本分光学会主催, ケイ光X線分析講習会（昭和 37 年 11 月) そて一部講演.

**）日本金属工業(株)川崎工場（川崎市大師河原上殿 町 4861 .

1) 岡, 根本, 蒼田: 分光研究, 11, 110 (1962).

2) 杉本: 分析化学, 11, 1169 (1962).

3) 杉本: 同上, 12, 475 (1963).

4) 杉本: 同上, 12, 539 (1963).

5) 杉本: 同上, 12, 164 (1963).

6) 杉本: 同上, 11, 1273 (1962).

7) 杉本: 同上, 12, 483 (1963). 
なお誤差の大きさほ，実用的な意味で綜合した誤差が $0.3 \%$ 程度の変動率になることを目標とした。

\section{2. 装置および測定条件}

分析装置は, ノレルコ製 $100 \mathrm{KV}$ 定電圧ケイ光 $\mathrm{X}$ 線分 析装置老使用乙, 基準分析条件は Table 1 に示す通り である・また個々の実験に㧍いて一部条件を变化させた 場合は，その都度これを示す。

Table 1. Experimental conditions

\begin{tabular}{l|l}
\hline \hline $\begin{array}{l}\text { X-ray tube } \\
\begin{array}{l}\text { Counter and H.T. } \\
\text { volt. }\end{array}\end{array}$ & $\begin{array}{l}\text { W-target, } 42 \mathrm{KV}, 15 \mathrm{~mA} . \\
\text { Crystal }\end{array}$ \\
$\begin{array}{l}\text { Condition of pulse } \\
\text { height analyser }\end{array}$ & $\begin{array}{l}\text { Gain: } 40 ; \text { Base line, 6 V. } \\
\text { Window: Integral }\end{array}$ \\
$\begin{array}{l}\text { Condition of } \\
\text { specimen }\end{array}$ & $\begin{array}{l}\text { Polished with No. 100 grits } \\
\text { emery paper on analytical } \\
\text { surface of 40 mm } \phi \text { cast } \\
\text { specimen which was spun } \\
\text { during measurement }\end{array}$ \\
Measured line & CrK $_{\alpha}, \mathrm{MnK}_{\alpha}, \mathrm{FeK}_{\beta}, \mathrm{NiK}_{\alpha}$, \\
$\mathrm{MoK}_{\alpha}$
\end{tabular}

\section{3. 実験および考察}

\section{1 時計およびスケールファクター切換えによる 誤} 差

ケイ光 X線分析法で, 定計数法または定時間法によっ て強度它測定する場合, 時計のもつ精度とスケールフォ クターの切換えによる誤差が問題となろう。

\section{1 .1 実験方法}

50サイクル信号波を基準とし，スケールフォクターを JIS の乱数表によって切換え, 各スケールフォクター についての所要時間を 30 回ずつ測定した. その結果を Table 2 に示す. また時計の誤差を Fig. 2 に示す.

\subsection{2 実験結果に対する考察}

スケールファクターは, Table 2 より換算して基準值 学 32 以上にとれば，全ての切換に関して，0.04\% 以内 の誤差であることが判った。 また時計の誤差は，ほとん ぞが start-stopによるものと考えられ，計数時間は他の

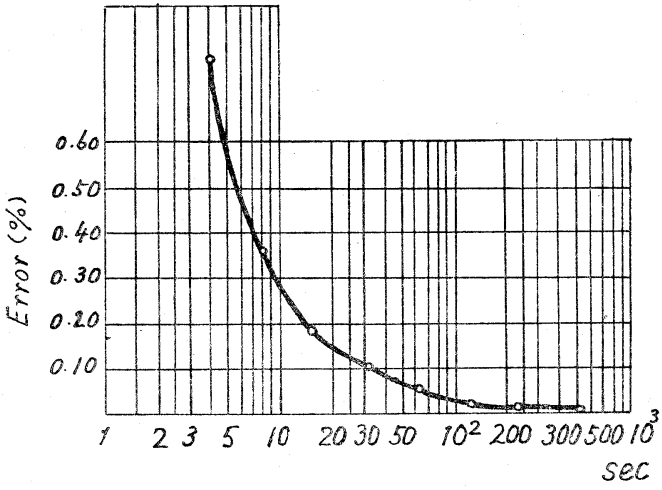

Fig. 2. Accuracy of the timer

誤差と関連して考慮せ稀ばならぬが，測定時間を 30 秒 以上とすれば $0.1 \%$ の变動におさまり，2分以上かけて も精度の向上は余り望めないことが判った。

\section{2 試料容器の差による誤差}

試料容器を 2 二以上使用する時は, 当然容器の数によ る䛊差が予想される．乙机注試料分析面とX線管との距 離, 入射, 出射 $\mathrm{X}$ 線と分析面のなす角度の变動等による ものと思われる。またこの装置には, 容器を入れる場所 が 2 力所あるため, この差も検討した。

\section{2 .1 実験方法}

鍛造丸棒学切断し, その切断面を研磨し, 両面の間に 成分的に差のないことを確認し, 試料容器, 試料保持台, 分析成分につき，分散分析を行なって検討した。

また試料面とX線管との距離の差によって生ずる誤差 については, 試料を試料容器の正規の位置より前後に動 かしてその変動をしらべた.その結果它 Fig. 3 亿示す.

\subsection{2 実験結果に対する考察}

Fig. 3 によって, 分析面の精度は $\pm 0.01 \mathrm{~mm}$ 程度 におさえねばなら始ことが判る。 また測定線のエネルギ 一やブラッグ角 $(2 \theta)$ によって, 变動率が異なり, モリ ブデン，ニオブの $K_{\alpha}$ 線には最高強度点が現われた。 このことは, 試料容器の精度が充分高いことが要求され ること定しているが，分析的にも多くの問題点が予想 される.この理由や対策については別報で述べたい.

Table 2. Accuracy of the timer for various scale factors

\begin{tabular}{l|lccccccc}
\hline \hline Scale factor & 2 & 4 & 8 & 16 & 32 & 64 & 128 & 256 \\
Mean value of time (sec) & 3.98 & 7.98 & 15.98 & 31.97 & 63.97 & 127.97 & 255.98 & 511.97 \\
Standard deviation & 0.031 & 0.029 & 0.031 & 0.036 & 0.037 & 0.033 & 0.028 & 0.029 \\
Coefficient of variation & 0.78 & 0.36 & 0.19 & 0.11 & 0.06 & 0.026 & 0.011 & 0.006 \\
\hline
\end{tabular}




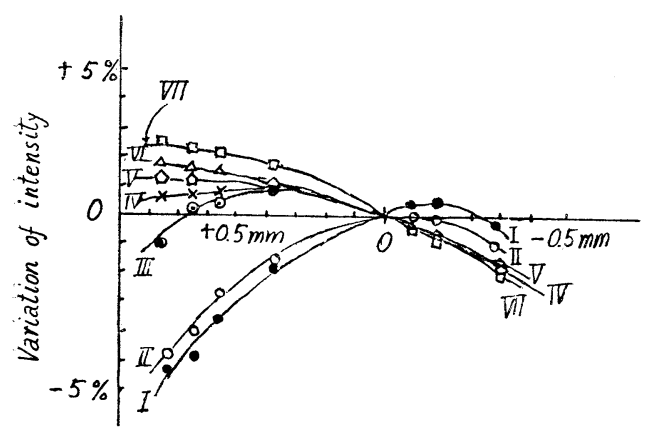

0 normal specimen position $+0.5 \mathrm{~mm}$ near to X-ray tube $-0.5 \mathrm{~mm}$ far to X-ray tube

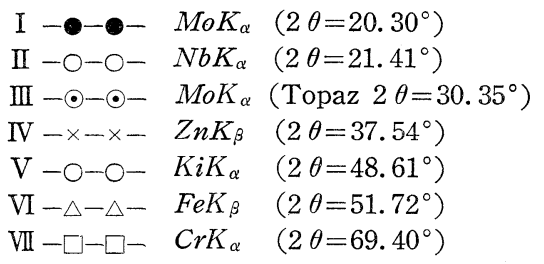

Fig. 3. Relation between the position the of specimen and the variation in intensity

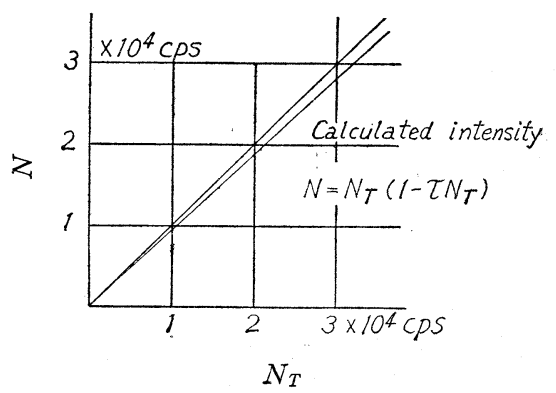

Fig. 4. Coincidence error $\tau=2.0 \mu \mathrm{sec}$

分散分析の結果は， $99.9 \%$ の信頼限界で試料容器， 試料保持台，分析成分等の間に有意差が認められなかっ た。

\section{3 数え落しによる誤差}

計数值は, 計数管の不感時間, 装置の分解時間等によ って $N=N_{T}\left(1-\tau N_{T}\right)$ の数え落しを生ずる.

ここに $N$ は測定計数值, $N_{T}$ は真の計数值を示す. し たがって $N$ が近次的に直線性をもつ範囲内で測定を行 なわぬ (Fig. 4 参照), 検量線に曲りを生ずる.もち ろえこの際分析を行なう範囲で直線を保てばよく，0点 它通る必要注ない。乙かし先述の近似式の成立つ範囲
内，安全它見て $\left(N_{T}-N\right) / N_{T}$ が 0.1 以内で測定すべき であろう。このような点を明らかにするために $\tau$ を測定 した。

\subsection{1 実験方法}

実験方法注，既報 ${ }^{2}$ に述べたので省略する。 $\mu_{\mathrm{sec}}$ であり， $N$ と $N_{T}$ の関係它 Fig. 4 に示す.

\section{3 .2 実験結果に対する考察}

3.1 に述べた時計の精度より 30 秒以上を測定秒数と し，計数誤差を $0.1 \%$ 程度におさえるための総計数量は $10^{6}$ カウントであるから, $3 \times 10^{4} \mathrm{cps}$ (count per second) 基準測定強度とした場合，約 $1.5 \times 10^{4}$ から $4.5 \times 10^{4}$ cps まで充分直線が保たれることが判った。

\section{4 ゴニオメーターの設定誤差}

ゴニオメーターを所定の位置に設定する際生ずる誤差 它検討した。

\section{4 .1 実験方法}

成分の異なる 2 コの試料を用意し, peak to background ratio の小さいモリブデンの $K_{\alpha}$ 線を用い， $1 / 100^{\circ}$ ごとにランダムに 2 回ずつ上下方向より測定し て, ゴニオメーターの設定による強度の变動を検討した。 この結果を Fig. 5 に示す. 図中強度比として示したの は， 2 コの試料の強度の比である.

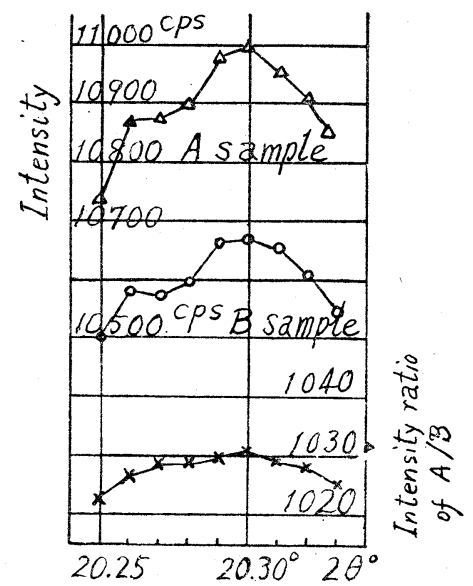

Fig. 5. Setting error of the goniometer at $M o K_{\alpha}$ peak

\section{4 .2 実験結果に対する考察}

Fig. 5 に示すように, 2 コの試料の比学とれば, $\pm 0.02^{\circ}$ の範囲内で変動率を $0.1 \%$ におさえることが 判った。 また上下方向よりの合わせ方に対する誤差は差 が認められなかった。 


\section{5 入力電源の変動による誤差}

工場における大力電源の変動は, 装置の問題ではない が, 特殊な熔解炉をもつ工場などでは, 大きな衝撃電流 が流れたり，大きな電生の変動が生じたりするので，非 常な誤差の原因となる。

Fig. 6 は，商用電源を用いた場合と定電圧発生装置を 用いた場合の比較で， $C r K_{\alpha}$ 線のピークにゴニオメータ 一を合わせ，経時間的な変動を求めたもので，このよう な工場では定電圧発生装置を用いる必要のあることが判 った.

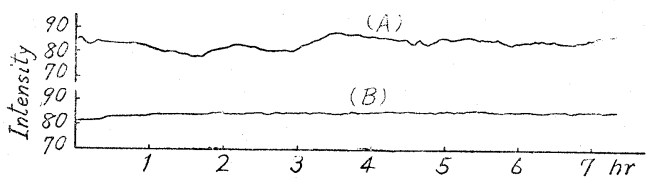

(A) Commercial source

(B) Stabilized source

Fig. 6. Difference in the stability due to the electric source

\section{$3.6 \mathrm{X}$ 線管の電圧，電流の変動による誤差}

$\mathrm{X}$ 線管の電圧，電流を所定の条件に設定した際，メー ターの再現性, 経時变化等によって誤差が生ずることが 予想される。
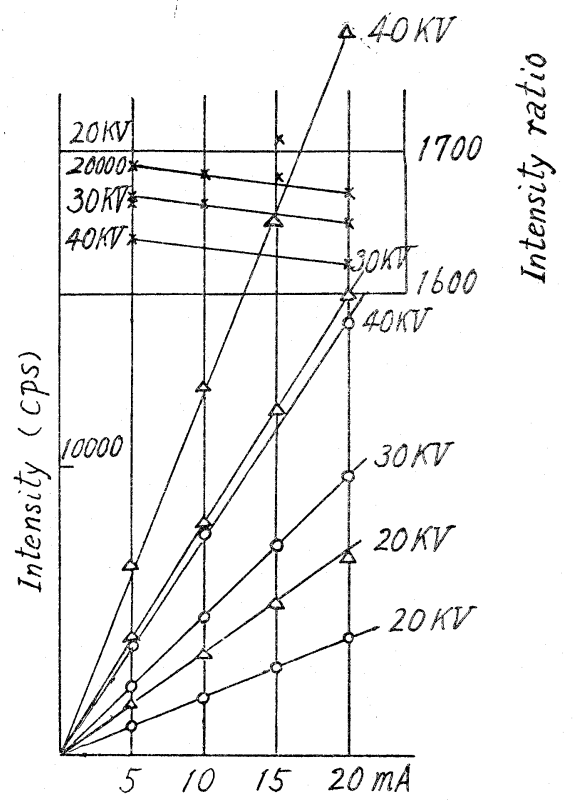

Fig. 7. Variation of the intensity due to the change of current of the X-ray tube $\left(N i K_{\alpha}\right)$
$\triangle N i \quad 10.20 \%$
○ $N i \quad 8.05 \%$

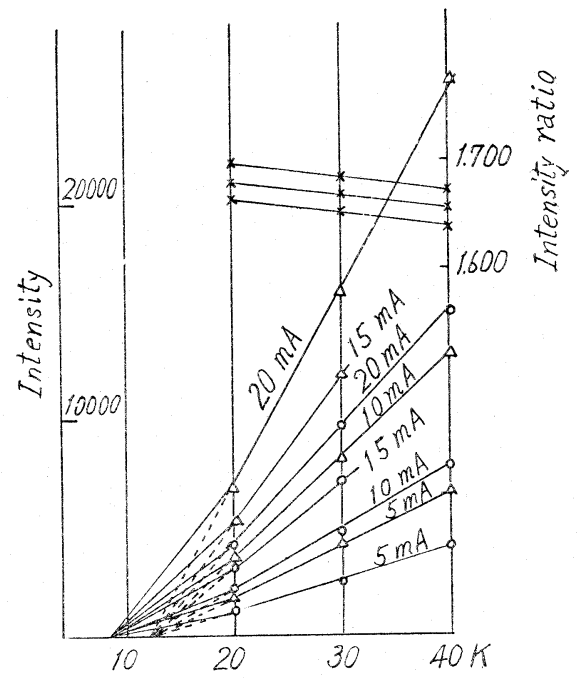

Fig. 8. Variation of the intensity due to the change of voltage of the $\mathrm{X}$-ray tube

\subsection{1 実験法}

ニッケル含有量の異なる 2 コの試料を用意し, 電圧, 電流を变化させて両試料のケイ光X線強度を測定した。

その結果学 Fig. 7, 8 に示す. 強度比として示したの は, 両試料の強度比である。

\section{6 .2 実験結果に対す当考察}

Fig. 7, 8 によって, $\pm 1 \mathrm{KV}$ 以内， $\pm 1 \mathrm{~mA}$ 以内に設 定し, 基準試料との比を取る方法で強度足測定すれば, 充分な精度で分析できることが判った．Fig 7 におい て, ニッケルの臨界励起電压よりやや高い点に収束する ように見えるが，これは本来電圧の変化に対して 2 次曲 線を示すものであるか，メーターの指示に誤差があるた わか明でない。しかし，一般に一次 X線で強度と電圧の 関係が

$$
I \alpha\left(V-V_{c}\right)^{2}\left(V \approx 2 \text { or } 3 \times V_{c}\right) \quad V_{c} \text { ：臨界励起電圧 }
$$
で示されるから，前者と見てよいと思われる。

\section{7 シンチレーションガウンターの印加電圧の変動} による誤差

3.6 と同様シンチレーションカウンターの変動によっ ても当然強度変化が生ずる.

\subsection{1 実験法}

3. 6.1 と同様の方法によって, 印加電圧を変化させて その变動を検討した. この場合は, ステンレス鋼の普通 分析する成分中波長の短いモリブデンと波長の長いクロ ム老対象とした。

実験結果を Fig. 9 に示す. 


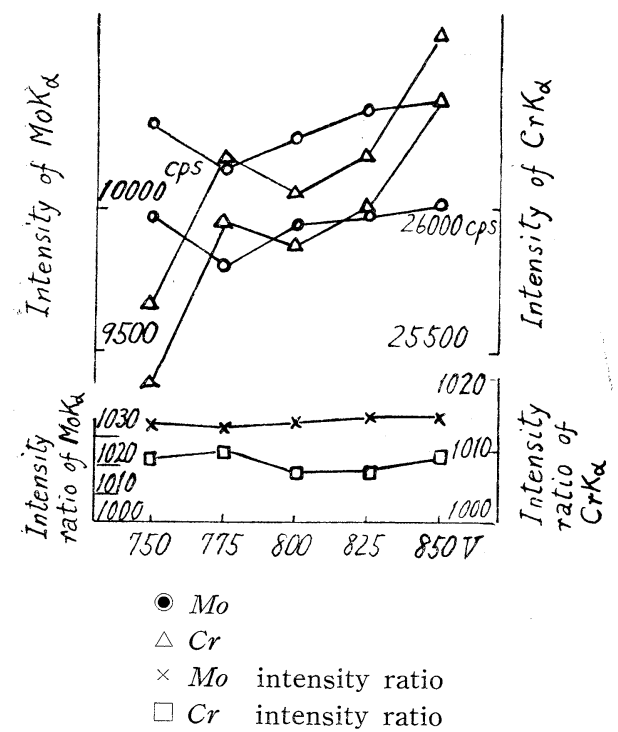

Fig. 9. Variation of the intensity due to the change of high voltage applied on the scintillation counter

3.7 .2 実験結果に対する考察

やはり一つの基準試料との比をとることによって，变 動率は非常に小さくおさえることが判る。

\section{8 装置の短期間変動による誤差}

装置をウォームアップさせる時閒学約 1 時間とって

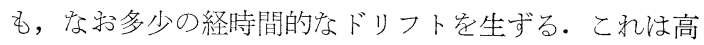
電生回路の安定に長時間を要することや, 光電子増倍管 の疲労などが原因していると思われる。

\subsection{1 実験方法}

同一試料の特定成分を 1 時間に 8 回ら゙つ，その強度变 化安測定した.その結果宏 Fig. 10 亿示す.

ここに示す強度比は, 続いて測定した 2 回の強度の比 它つぎつぎにとって行なったものである。

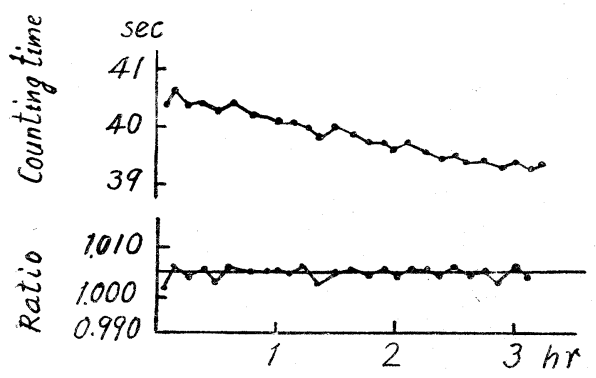

Fig. 10. Drift of $C r K_{\alpha}$ intensity during heat rum

Total count: $1,024 \times 10^{3}$

\section{8 .2 実験結果に対古る考察}

Fig. 10 でわかるように,電源を入れてから3時間の間 は，大きなドリフトを生ずるが，やはり一つの基準物質 との比をとれば充分小さくおさえることが可能である。

\section{9 長期間変動}

長期間変動は, 装置の変動中最も処理のめえどうなも のであるが，すでに報告したので省略する5)。

\section{4. 総括}

機器に帰因すると思われる誤差の大きさについて検討 した結果，比較的誤差の大きい設定上の誤差と短期間変 動は，一つの基準試料との比をとる対比法によってほぼ 消去できることが判った.

したがって精度のよい測定を行なうためには, 装置自 体に対比法またはこれに变る方法が行なえるような機構 であることが必須である。

しかし，対比法をとることは，測定を 2 回行なって， 一方の基準試料との比圭とるため, 測定時間が約 2 倍要 すること, 統計变動が約 $\sqrt{2}$ 倍悪くなるという久点が ある.ことに本分析法は, 迅速分析法として大きな意義 它もつものであるから，測定に 2 倍㱏要するということ は，非常に大きな欠点であるといえる.

その他の利点としては, 前述のように測定精度が向上 するだけでなく，現場作業では基準試料として既知の試 料を行なうことによって，装置の設定上の間違いがあっ た時 未然にとれを発見できること，また講習会の報告8 でのべたように，異なった装置でもほとんど測定值に変 動が尔い等の非常に勝れた面を発揮することができる。

以上の点を綜合すると, ケイ光X線分析法で注対比法 で分析することが非常に有効であると結論できよう。

Table 3. Reproducibility for the main elements in stainless steels

\begin{tabular}{c|c|c|c}
\hline \hline Type & Element & $\begin{array}{c}\text { Reproducibi- } \\
\text { lity(standard } \\
\text { deviation) }\end{array}$ & $\begin{array}{c}\text { Coefficient } \\
\text { of variation }\end{array}$ \\
\hline \multirow{2}{*}{ SUS 27 } & $\mathrm{Cr}(18 \sim 19 \%)$ & $0.050 \%$ & $0.27 \%$ \\
& $\mathrm{Ni}(8 \sim 10 \%)$ & 0.024 & 0.27 \\
SUS 32 & $\mathrm{Cr}(17 \sim 18 \%)$ & 0.049 & 0.27 \\
& $\mathrm{Ni}(10 \sim 12 \%)$ & 0.031 & 0.28 \\
SUS 42 & $\mathrm{Cr}(22 \sim 24 \%)$ & 0.059 & 0.22 \\
& $\mathrm{Ni}(19 \sim 22 \%)$ & 0.026 & 0.13 \\
SUS 41 & $\mathrm{Cr}(22 \sim 24 \%)$ & 0.057 & 0.25 \\
& $\mathrm{Ni}(12 \sim 15 \%)$ & 0.037 & 0.28 \\
\hline
\end{tabular}

8）杉本：分光研究， 11，262（1962）. 